\title{
Driving informal institutional change: the European Parliament and the reform of the Economic and Monetary Union
}

\section{Magnus G. Schoeller \& Adrienne Héritier}

To cite this article: Magnus G. Schoeller \& Adrienne Héritier (2019) Driving informal institutional change: the European Parliament and the reform of the Economic and Monetary Union, Journal of European Integration, 41:3, 277-292, DOI: 10.1080/07036337.2019.1599373

To link to this article: https://doi.org/10.1080/07036337.2019.1599373

(c) 2019 The Author(s). Published by Informa

UK Limited, trading as Taylor \& Francis Group.

曲 Published online: 16 May 2019.

Submit your article to this journal $\widetilde{ }$

山 Article views: 583

Q View related articles ¿

View Crossmark data \lceil 


\title{
Driving informal institutional change: the European Parliament and the reform of the Economic and Monetary Union
}

\author{
Magnus G. Schoeller ${ }^{\mathrm{a}}$ and Adrienne Héritier ${ }^{\mathrm{b}}$
}

${ }^{a}$ Centre for European Integration Research (EIF), Department of Political Science, University of Vienna, Vienna, Austria; ${ }^{b}$ Robert Schuman Centre for Advanced Studies, European University Institute, Florence, Italy

\begin{abstract}
With the Lisbon Treaty, the European Parliament (EP) obtained codecision rights in economic governance for the first time. Soon afterwards, the outbreak of the eurozone crisis required a reform of the Economic and Monetary Union (EMU). When negotiating EMU reform, the EP sought to push its rights beyond the Lisbon provisions, so as to obtain an informal institutional change to its benefit. How and under which conditions did the EP extend its informal powers successfully - and when did it fail? By focusing on two crucial strategies - delaying and arena-linking - we compare instances of EMU reform where the EP succeeded in reaching an informal empowerment to cases where it failed. We find that the urgency of decision-making and its distributional consequences influence the EP's chances of success. While urgency plays a crucial role in times of crisis, distributional consequences come to bear in policies where core state powers are at stake.
\end{abstract}

\section{KEYWORDS}

European Parliament; institutional change; Economic and Monetary Union; Eurozone; European Union

\section{Introduction}

In recent decades the EP has been extremely skilful in pushing forward its institutional agenda in the direction of widening its formal and informal powers (Hix and Høyland 2013). Under the Lisbon Treaty, the EP was given new formal competences in some areas of EU economic governance, and it has subsequently attempted to extend these powers informally to other areas - albeit with varying success (Fasone 2014; O'Keeffe, Salines, and Wieczorek 2016; Rittberger 2014). Therefore, we ask: How and under which conditions did the EP extend its informal powers successfully - and when did it fail?

In answering this question, we draw on a bargaining theory of institutional change. We argue that the EP made extensive use of two crucial bargaining strategies, namely delaying and arena-linking. Yet, as we show in the article, these strategies do not work under all circumstances. While the success of delaying depends on the urgency of the issues under negotiation, arena-linking only works if it does not imply significant distributional consequences for the more powerful member states. 
In order to obtain our results, we compare instances of EMU reform in which the EP succeeded in reaching informal institutional change in its favour to cases in which it failed to do so. Based on original interview material, we focus on the most important measures of eurozone crisis management, namely the 'Six-pack' legislation, the European Stability Mechanism (ESM), the Fiscal Compact and the Banking Union.

The article thus adds to two different strands of literature. First, by investigating the conditions under which the EP succeeds in expanding its institutional powers, we contribute to the research on the EP's (self-)empowerment (Hix and Høyland 2013; Farrell and Héritier 2003; Rittberger 2003) and its informal involvement in EU politics (Reh et al. 2011). Second, the article adds to ongoing research on the EP's current role and power in EMU (Bressanelli and Chelotti 2018; Crum 2018; Fromage 2018; Warren 2018).

In a first step, we will present our theoretical approach and derive our expectations. The second step will then be devoted to the empirical analysis. The conclusion summarizes our argument and contextualizes the empirical findings.

\section{Changing institutional rules: a power-based bargaining explanation}

When analysing the EP's efforts to extend its institutional powers, we base our argument on bargaining theories of institutional change (Héritier 2007). At the micro-level, we assume that actors are boundedly rational and do not have perfect information as they face cognitive limits and transaction costs of information collection. Moreover, actors seek to maximize their institutional power in order to increase their influence over policy outcomes. At the macro-level, we assume that actors interact in a given institutional context. We understand institutions as sets of man-made rules of behaviour that facilitate and restrict social interactions (North 1990). They guide interaction in the accomplishment of joint tasks, such as legislation, and they allow actors to incorporate expectations regarding the actions of others into their own decision-making (Lake and Powell 1999). We specifically focus on the question of what the distributional implications of institutional rules are, how a change of rule comes about, who it favours and who it disadvantages (Knight 1992; Snidal 1996, 125).

Furthermore, we regard institutional rules as incomplete contracts. Incompleteness flows not only from bounded rationality and the high transaction costs of collecting information, but also from the diversity of interests of those actors that are negotiating the initial formal rule. In order to lower transaction costs of negotiating, and - given diversity of preferences - to allow for an agreement at all, actors often settle for rather vague formulations. As a result, the formal rule will be subject to renegotiation in the course of its application, and may thus give rise to a new informal institutional rule. ${ }^{1}$

Why some actors win out and others lose in these re-negotiations, is accounted for by the relative power of an actor as well as environmental conditions, such as the existing decision-making rule or an external shock (Knight 1995; Krasner 1991; Sebenius 1992). First, an actor's available fall-back position should negotiations fail determines the new informal rule. The longer the time horizon of an actor, the lower the intensity of her preferences, and the more patient in the bargaining process she will be. Patience enables her to make credible threats with regard to one or more items of negotiation and thus enhances her overall position in the bargaining process (Knight 1992, 41f, 
127-132). Second, the actors' formal institutional rights at $t_{1}$ determine their ability to influence the outcome of the bargaining process (e.g. by setting the agenda or putting in a veto).

Hence, since pre-existing institutions lend strategic advantages to those who control them, any attempt to change them must surmount considerable resistance (Sened 1991, 398). If the EP wants to re-negotiate a formal institutional rule to its advantage during application, it therefore needs to employ bargaining strategies which build on its longer time horizon and its pre-existing institutional rights (see above). In the following, we focus on two such strategies which are very frequently employed to that purpose: delaying and arena-linking.

First, the EP's greater time horizon and insensitivity to failure as compared to the Council Presidency and member state governments (Farrell and Héritier 2003, 582) as well as its new co-decision rights in economic governance obtained by the Lisbon Treaty (see below) allow the EP to delay the decision-making process (see Gino and Moore 2008 , 374). Member state governments, in their sum, are constantly exposed to voters' critique in elections; voters' responses to European policies almost exclusively target national governments, and if discontent, they put the blame at their governments' feet, possibly voting them out of office.

Moreover, the relatively high turnover in the Council has a negative impact on its bargaining power in inter-institutional negotiations. In particular, high turnover 'counteracts the accrual of experience, produces less institutional and procedural knowledge, provides fewer opportunities for contact among incumbents, and weakens networks of internal and external communication' (Scherpereel and Perez 2015, 666). Thus, using the DEUII data set, Scherpereel and Perez (2015) confirmed that high levels of turnover in the Council clearly hurt its bargaining success vis-à-vis EP and Commission.

By contrast, members of the EP (MEPs) are exposed to electoral 'judgment' only every five years (and even then voter turn-out is low). This relative personnel constancy allows the EP to be more 'patient' and possibly refuse to agree to certain legislation until its institutional demands are accommodated. In this way, the EP can seek to reap further powers in inter-institutional negotiations. We thus conjecture that

if the EP has the formal right to block a decision, is more patient than the member states, and uses a delaying strategy, it obtains an informal institutional change to its benefit.

Second, especially when the EP lacks the necessary competences to block a decision, it may establish an informal link to another decision-making arena. In this way the EP can withhold its support for a decision in an arena where it has full competences until it obtains more informal institutional powers in the arena with no competences. By making the outcome in one arena dependent on the outcome of another arena, the EP may thus take the decision-making process hostage (Farrell and Héritier 2007, 292). ${ }^{2}$ We therefore submit that

if the $E P$, using a formal veto in one arena $X$, creates a leverage in another linked arena $Y$ in which it has no formal vote, it obtains an informal institutional change in its favour in arena $Y$.

\section{Empirical analysis}

Since the entry into force of the Lisbon Treaty in December 2009, the EP's competences in the field of economic governance have primarily been based on Art. 121 TFEU. It 
grants the EP co-decision rights for multilateral surveillance 'to ensure closer coordination of economic policies and sustained convergence of the economic performances of the Member States' (Art. 121.3 TFEU). The same applies to provisions relating specifically to members of the eurozone (Art.136 TFEU) (Fasone 2014, 171). ${ }^{3}$

The introduction of co-decision as the ordinary legislative procedure (OLP) in this area replaced the cooperation procedure, which had allowed the Council to adopt a legislative proposal despite the rejection of the EP. This formal increase of the EP's competences in the Lisbon Treaty coincided with the onset of the eurozone crisis. The mentioned Treaty articles provided the main legal basis for the EU's response to the crisis. For the EP, the new formal competences became effective in a time of acute financial and economic crisis and thus signified an enormous increase of workload and activity in the field of economic and financial governance.

\section{Methodology}

When empirically assessing the two conjectures proposed above, we will engage in systematic pairwise comparisons of cases in which the delaying and the arena-linking strategies were used respectively. As we expect that the respective strategies do not work under all circumstances, we choose cases in which the EP obtained an informal institutional change and compare them to cases where the application of the strategies did not lead to any institutional improvement for the EP. Using this 'backward-looking' approach (Scharpf 1997, 22-27) we will identify factors responsible for the success or failure of the application of the two strategies. Thus, this is not a theory test but an explorative analysis that goes beyond re-testing established hypotheses in order to inductively identify new variables or scope conditions (see George and Bennett 2005, 75 , 'heuristic case study'). The purposive case selection on outcomes, reflecting the full variance of the dependent variable and thus the whole contrast space suggested by the research question (Collier and Mahoney 1996, 62f, 66f), allows us to contrast instances where the traditional theoretical propositions anticipate the outcome with those where they fail. These paired comparisons enable us to identify further influencing variables or scope conditions that account for the difference in outcomes.

Our case studies comprise the most important measures in dealing with the eurozone crisis, namely the 'Six-pack' legislation, the European Stability Mechanism, the Fiscal Compact and the Banking Union. As regards the assessment of the delaying strategy, we compare the EP's success in obtaining an informal institutional change in the negotiations of the Single Supervision Mechanism (SSM) to the failure of obtaining any change in its favour regarding the Macroeconomic Imbalances Procedure of the Six-Pack. In order to assess the arena-linking conjecture, we compare two cases in which the EP succeeded in using arena-linkage, namely the SixPack legislation and the Fiscal Compact, to the shaping of the ESM, where arenalinkage failed.

Our data are based on the analysis of official documents and nine semi-structured élite interviews conducted with one MEP and several officials of the EP, the Council of Ministers and the Commission. We selected interviewees who were directly involved in the issues of interest and triangulated the information obtained from EP staff with statements from Council and Commission officials. In order to obtain valid information, 
we guaranteed strict confidentiality to the interviewees. If they agreed, we recorded the interviews. Otherwise we made detailed notes.

For the sake of analytical clarity, we treat the EP as a unified actor when negotiating with the other institutions. To be true, the divergence of preferences among MEPs is just as large as the divergence among member states. However, our analysis of the decisionmaking process starts only once the position of the EP has been defined (e.g. by a common resolution or a negotiation mandate). In a specific, separate analytical step one might analyse the process of preference accommodation within the EP, but that is not our aim here (see Lake and Powell 1999, 13-16, 'boxes within boxes' approach; Scharpf 1997, 52f). ${ }^{4}$

\section{Delaying: SSM (success) versus macroeconomic imbalances procedure (failure)}

If the EP has the formal right to block a decision, is more patient than the member states, and uses a delaying strategy, it obtains an informal institutional change to its benefit.

A case in which the EP successfully used the delaying strategy (in combination with arenalinking) is the negotiation of the SSM and the related inter-institutional agreement with the $E C B$, which gives the EP access to information on the situation of European banks and SSM proceedings. Next to the SSM, the Banking Union consists of the Single Rule Book, the Single Resolution Mechanism (SRM) and the Single Resolution Fund (SRF). The EP was very supportive of the overall project of a European Banking Union (Interview 3). In fact, it was the EP which as early as 2010 had proposed the idea of a Banking Union in the 'De La Rosière Report', but at that time it was rejected by Finance Ministers. However, in 2012 the Council proposed the idea themselves (Interviews 2, 3).

In the negotiations, the EP strongly insisted on more transparency of the SSM procedures (Interview 2). As co-decider on the regulation establishing the SSM and conferring specific tasks to the ECB (Regulation No 1022/2013), the EP accepted the legislative proposal only after obtaining better access to information from the ECB in its supervision of banks. For that purpose an inter-institutional agreement ${ }^{5}$ was concluded with the ECB providing that the ECB regularly inform the EP on the surveillance process. More precisely, the agreement provides that the ECB submit a yearly report to the EP on the execution of its task, that the Chair of the Supervisory Board may be invited to additional 'ad hoc exchanges of views on supervisory issues with Parliament's competent committee', and that the ECB 'should provide Parliament's competent committee at least with a comprehensive and meaningful record of the proceedings of the Supervisory Board that enables an understanding of the discussions, including an annotated list of decisions' (European Central Bank and European Parliament 2013).

Next to these enhanced rights of information, the EP also obtained new de facto powers regarding the appointment of the Single Supervisory Board's executive staff. From the outset the EP had sought to improve the accountability of the decision-making authorities under the SSM (and SRM and SRF) by seeking a role in the governance of various boards and establish rules that the latter report to the EP (Interview 2, 3). By delaying the required regulation for establishing the ESM (see above), the EP obtained such rights in the form of the inter-institutional agreement:

"A public hearing of the proposed Chair and Vice-Chair of the Supervisory board shall be held in Parliament's competent committee. Parliament shall decide on the approval of the 
candidate proposed by the ECB for Chair and Vice-Chair through a vote in the competent committee and in plenary. [...] If the proposal for the Chair is not approved, the ECB may decide either to draw on the pool of candidates that applied originally for the position or to re-initiate the selection process [...]" (European Central Bank and European Parliament 2013).

Whereas delaying played out successfully for the EP in the case of the SSM, it failed when the EP initially withheld its acquiescence to the implementation rules of the socalled 'Macroeconomic Imbalances Procedure', which brought about only a partial informal change that did not favour the EP. The Six-pack legislation includes measures to strengthen budgetary surveillance as well as a new procedure to help prevent and correct macroeconomic imbalances. The legislative package consists of 5 regulations and one directive. Four of the six legislative acts were decided under OLP.

The Macroeconomic Imbalance Procedure is an alert mechanism, which provides for a scoreboard based on indicators focusing on the most relevant dimensions of macroeconomic imbalances and losses of competitiveness. If the Commission comes to the conclusion that there are severe imbalances, it will recommend an excessive imbalances procedure to the Council; this is part of the corrective arm of the new procedure (Bouwen and Fischer 2012).

In the Regulation on the Prevention and Correction of Macroeconomic Imbalances (No. 1176/2011) some vague provisions were introduced that needed specification through delegated legislation. In the interpretation of these incomplete institutional rules, a conflict emerged over the choice of either 'delegated acts' (Art. 290 TFEU) or 'implementing acts' (Art. 291 TFEU). ${ }^{6}$ When deciding how to flesh out the scoreboard regime, the Commission first proposed to define these indicators on its own. Following resistance from both Council and EP, the Commission and the EP proposed delegated acts whilst the Council wished to use an implementing act. The EP prefers delegated acts because it has co-equal rights with the Council to revoke a Commission rule. The Council prefers implementing acts because they imply a practice which is similar to the old comitology system, in which member state representatives together with the Commission issue rules. A deadlock ensued after a round of negotiations as the EP refused to accept the Commission proceeding under implementing acts.

However, instead of agreeing on delegated acts, the outcome of the negotiation process was the use of an informal new procedure which is neither Art. 290 TFEU nor Art. 291 TFEU, the so called 'compromise' rule. The respective recital 12 of the Regulation says

'The Commission should closely cooperate with the European Parliament and the Council when drawing up the scoreboard and the set of macroeconomic and macrofinancial indicators for Member States. The Commission should present suggestions for comments to the competent committees of the European Parliament and of the Council on plans to establish and adjust the indicators and threshold. The Commission should inform the European Parliament and the Council of any changes to the indicators and threshold and explain its reasons for suggesting such changes.'

Note the difference to the 'real' use of a delegated act used in another Six-pack regulation on the effective enforcement of budgetary surveillance (No 1173/2011), under which the delegation may be revoked at any time by the Parliament or by the Council (Art. 11.2, and 3). 
In a nutshell, in the case of the Macroeconomic Imbalances Procedure, a conflict arose between the Commission, the Council and the EP regarding the definition of the economic indicators in the scoreboard. The conflict centred around the interpretation of the legal rules when deciding how to flesh out the scoreboard regime. This conflict gave rise to a new informal rule (set out in the recital of the regulation and not in the legal text) about how to specify the formal rule, which due to its political importance became de facto binding. Thus, the EP could not achieve its goal of employing delegated acts despite using a delaying strategy. On the contrary, alongside with the Council, it was partially disempowered under the 'compromise rule'.

Hence, while in the case of Banking Union's SSM the EP obtained informal institutional changes obliging the ECB to offer information on the situation of European banks and SSM proceedings and including the EP in the appointment of the SSM's executive staff, the strategy failed in the case of the Macroeconomic Imbalance Procedure. Comparing the two cases, the question emerges as to how we may account for these differences in outcome.

We propose that the underlying factor which accounts for success or failure of the delaying strategy is the generally perceived urgency to act in the specific decisionmaking situation:

The delaying strategy will be effective only if the generally perceived urgency of making a certain decision is high.

Time pressure or urgency plays an important role in negotiation processes. Above we argue that in negotiations under time pressure, it is the more patient actor who will obtain the better outcome. Here we focus on the relative time pressure resting on all actors when solving a collective action problem and compare the perceived urgency of the needed problem solution in two decision situations. Assuming that the opportunity of single actors to use a delaying strategy varies according to their respective fallbackposition, we argue that the effectiveness of delaying increases with the perceived urgency. Urgency can be measured in terms of the costs which would arise for all actors as a consequence of non-action. These can be electoral costs, reputational costs, or negative overspill effects for the economy.

In the case of the Banking Union legislation, the negotiating actors' perceived time costs were higher than in the implementation of the details concerning the Macroeconomic Imbalances Procedure. In the first case, actors still perceived a high risk of fragmentation in the eurozone despite the easing effect of the ECB's prior announcement of Outright Monetary Transactions ('whatever it takes'). The actors feared that a fragmentation of the eurozone could still be caused by single member states running unsustainable debt levels or by system-relevant banks (Interview 6T). Therefore, actors perceived a high urgency to break the vicious cycle between sovereigns and banks, which could have easily resulted in the fragmentation of the eurozone as a whole ('spill-over'). While the ECB's 'whatever it takes' made sure that the markets did not attack anymore single member states for the time being, the purpose of the banking union was to contain (or even eliminate) the contagion risk should a member state get into trouble nonetheless. In this sense, the banking union was an urgent measure to ensure the lasting effect of the ECB's announcement (see e.g. Angelini and Grande 2014; Weidmann 2013). 
In the second case of the Macroeconomic Imbalances Procedure, in contrast, 'only' the definition of detailed indicators on how to measure macro-economic imbalances were at stake. What is at issue here is delegated legislation, i.e. the implementation of a set of legislative provisions of the Six-Pack, but not legislation itself. In other words, the issue was not urgent as it could have easily been postponed, with the Six-Pack being adopted nevertheless. Hence, as urgency was higher in the first case, the delaying strategy played out successfully and the EP obtained an informal institutional change to its benefit in the case of the Banking Union.

\section{Arena-linking: six-pack and fiscal compact (success) versus ESM (failure)}

The second strategy which may lead to an informal institutional change to the advantage of the actor with less competences is arena-linkage. Under this strategy, an actor takes hostage of one arena, in which she has co-decision competences or a veto-right, in order to obtain new powers in another arena in which she has no competences. We therefore claimed:

If the $E P$, using a formal veto in one arena $X$, creates a leverage in another linked arena $Y$ in which it has no formal vote, it obtains an informal institutional change in its favour in arena $Y$.

We first analyse two cases in which the EP applied arena-linking successfully and obtained an informal institutional change it its favour: namely the negotiations on the Six-Pack legislation on the one hand, and the Fiscal Compact on the other hand. We then present a case in which the EP applied the same strategy, but failed to obtain an informal institutional change to its advantage. We then ask what might explain the difference in the outcomes and formulate a conjecture as to the relevant factor.

In the negotiations on the Six-Pack, where the EP had a formal right of co-decision in only four of the six legislative acts, it succeeded in establishing a cross-arena link between the four co-decision arenas and the two (non-binding) consultation arenas. By threatening to veto the decisions in the co-decision arenas, it was given de facto codecision in all six legislative proposals.

From the very beginning of the negotiations, it was a general concern of the EP to make the Six-Pack procedures less bureaucratic and to allow for more transparency and accountability to the EP: for instance, the EP aimed at inviting national finance ministers to defend national budgets before the EP (Interviews 2, 3, 5) and 'preventing Council from taking backroom decisions' (Interview 5). In order to increase its influence, the EP insisted on dealing with the regulations and directives as a package, thereby establishing a cross-arena linkage. Hence, once the six legislative texts were tabled together, it was impossible for the Council to exclude the EP from those acts where it formally had no co-decision powers, because the EP credibly threatened to block the other regulations (Interviews 2, 6, 7).

As one interviewee from the Council explained:

"This typically is hijacked by the Parliament and they have seen that as a package together from the outset [...]. But then in the negotiations you come to the point where you say: 'Look, Parliament, on those two we are happy to have your opinion, but in principle we don't have to care'. Now, if you say that, you are in big trouble because then you won't get your compromise on the other four. So I think once you allow these being handled together 
you are trapped. Let's say you, as Council, there was no other way than to accept that you handle the six together and that basically means that the Parliament was negotiating on those two where it was not co-decision-maker; it would negotiate on it as on the other [...]. So basically we Council would have the same outcome even if the Parliament were co-legislator [...]. This has been lost. The Parliament has basically gained a full role of co-legislator de facto" (Interview 7; italics added by the authors).

The EP managed, for instance, to insert the Economic Dialogues into a regulation where it was not co-decider (No 1177/2011, Art. 2a). These Dialogues allow the EP to invite the Presidents of the Council, Commission, European Council, and Eurogroup as well as member state representatives to discuss economic governance issues that fall under the EP's competences. The reason for this success was the use of arena-linkage. As a MEP, who was closely involved in the negotiations, put it: 'A little friendly blackmail not to adopt the rest of the legislation (under co-decision) helps' (Interview 2).

In short, by means of arena linkage, the EP obtained an informal rule change, namely de facto co-decision power in arenas that do not foresee any binding decision-making rights for the EP.

Yet another example of a successful application of arena-linking are the Fiscal Compact negotiations. Although the EP had no rights of decision-making in the case of the Fiscal Compact, which is an international treaty outside EU law, it influenced the treaty content on a few crucial points by using its rights as co-legislator under the socalled Two-Pack legislation as a lever. Thus, it was not only invited as an observer to the negotiations, but it obtained the informal right of fully participating in the working group negotiating the international agreement.

The Fiscal Compact is an international treaty, which was agreed upon at the European Council of 8 and 9 December 2011. The negotiations took place in the two months after, so that the treaty could be endorsed at the informal European Council of 30 January 2012. It was formally signed on 2 March 2012 by all EU member states except the UK and the Czech Republic. The signatories commit themselves to a balanced budget, an automatic correction mechanism established by their national law at a constitutional or equivalent level, and independent national institutions to monitor compliance. The Fiscal Compact has to be incorporated into EU law within five years after its entry into force.

The three EP delegates, which were formally invited as observers to the treaty negotiations, were Gualtieri, Brok, Verhofstadt, and - as a substitute - Cohn-Bendit. Their objective, however, was much more ambitious than merely observing. The EP's overall target was to make the Fiscal Compact as similar as possible to EU law, so that it could be easily integrated into the EU legal framework at a later point in time. Here the EP presumably had the support of the Commission, which shared the same interest (Interview 3; Fasone 2014, 179).

Parallel to the Fiscal Compact negotiations, the Two-Pack regulations were negotiated under OLP. Given that the two legislative proposals contained important elements that were not covered by the substance of the Fiscal Compact (e.g. ex-ante budgetary coordination with the Commission), member states had a strong interest in finalizing the Two-Pack. Indeed, the European Council as well as the Danish Council Presidency repeatedly urged the EP to come to a rapid adoption of the Two-Pack (Bressanelli and Chelotti 2016, 520). ${ }^{7}$ This gave the EP the opportunity to establish a cross-arena linkage 
by threatening to block the Two-Pack negotiations if its requests regarding the Fiscal Compact were not sufficiently taken into account (Interview 6). In substantive terms, the EP thus achieved two of its objectives: it managed to introduce a 'repatriation clause' to the Treaty, according to which the Fiscal Compact is to be incorporated into EU law five years after its entry into force (Interviews 1, 6). Secondly, the EP achieved that also those contracting parties whose currency is not the euro can participate in the newly established Euro Summits if they concern 'the competitiveness for the Contracting Parties, the modification of the global architecture of the Euro area and the fundamental rules that will apply to it in the future' (TSCG 2012, Art. 12.3).

In sum, by establishing a cross-arena linkage, the EP obtained the informal institutional right to participate in the negotiation process and thereby to wield substantive influence in an arena where it does not possess any formal competences.

We now turn to a case in the area of economic governance in which the EP did not succeed in obtaining an informal institutional change to its advantage through the use of arena-linking, namely the shaping of the ESM. The ESM is based on an international agreement outside EU law which does not allow for any influence on the part of the EP. However, in order to put the ESM on sound legal ground, it was deemed necessary to amend Article 136 TFEU (De Witte 2011, 5f). ${ }^{8}$ To avoid referenda in the member states and to speed up the procedure, this treaty amendment was supposed to take place under the simplified treaty revision procedure (Art. 48.6 TEU), to which the EP needed to be consulted and had to give its initial consent.

Hence, while it was clear that the ESM was going to be an intergovernmental organization outside EU law, member states needed the Treaty amendment and thus the EP's approval. Therefore, the EP was in a position to link arenas and make demands. In fact, the EP asked to be involved in the ESM negotiations (Library of the European Parliament 2012, 4; Rittberger 2014, 1178f). In its Resolution of 18 January 2012 on the European Council of 8-9 December 2011, for instance, the EP requested 'that Parliament participates in the same way in these negotiations'. ${ }^{9}$ However, member state governments ignored these requests. Also as regards the substance of the ESM treaty, the amendments proposed by the EP were entirely disregarded by the member states (Fasone 2014, 170). As the authors of a related study for the EP note: 'The EP was not involved in the negotiations and the treaty establishing the ESM does not make any reference to this institution' (Alcidi, Giovannini, and Piedrafita 2014, 46).

Thus, we conclude that the EP did not succeed in linking the ESM negotiations to the simplified revision procedure of the amendment of article 136. Without the EP's consent to this procedure, the ESM could not have been established. The EP was well aware of the strategic significance of its consent and would not have given it away for free. ${ }^{10}$ Still, the EP could not use this veto-right in one arena, the simplified revision procedure, to realise its goal of participating in another arena, namely the ESM negotiations with the member states. Hence, in the case of the ESM treaty, the strategy of arena-linking did not work for the EP.

This raises the question as to why the EP failed in the case of ESM, but not in the case of the Fiscal Compact? Both Treaties are international agreements outside EU law that offered the EP the opportunity to link negotiations to another arena in which it had greater influence. In the case of the Fiscal Compact, this was the Two-Pack legislation, in which the EP was co-legislator. In the case of the ESM, this was the simplified treaty 
revision procedure, which required the EP's consent. Yet, only in the first case did the EP manage to apply its lever.

We propose that beyond the arena linking explanation, there must be an additional explanatory factor, which may be sought in the specific issue at stake. In the case of the ESM, a significant redistributive issue for the more powerful creditor states was at stake, which consisted in large sums of taxpayers' money. The Fiscal Compact, by contrast, concerned questions of budgetary discipline and control over national budgeting procedures, which primarily affect the less powerful 'debtor states'. ${ }^{11}$ In other words: The Fiscal Compact (and the Six-Pack) did not grant any access to national budgets, which is why the more powerful creditor states had nothing to lose. The ESM, by contrast, was about the actual appropriation of taxpayers' money and thus implied distributional consequences. We therefore argue:

If redistributive issues concerning the more powerful actors are at stake, the use of arenalinkage by the actor with less competences will fail.

The underlying rationale is that member states will yield to arena-linking only if the costs of accommodating the EP's demands are lower than the potential gains in the arena that is taken hostage. Thus, if the EP's demands imply a possible or actual loss of core state powers, member states are likely to forgo the potential gains in the linked arena. In both cases, the Fiscal Compact and ESM, the EP had no formal rights to participate in the negotiations and was therefore dependent on the member states' willingness to include it. Their resistance was much greater in the case of the ESM because this treaty concerned the actual use of national taxpayers' money (core state powers). This made the ESM a more sensitive issue than the Fiscal Compact, which regards only the control, but not the appropriation of national budgets. This difference helps explain why the EP successfully used the arena-linkage strategy in the case of the Fiscal Compact, but failed in the case of the ESM.

\section{Conclusion}

Based on a bargaining theory of institutional change, we argue that institutional rules are incomplete contracts which are renegotiated in the course of their application. We analyse how the EP uses these opportunities of renegotiation in order to push its de facto powers beyond the formal rights granted by the Lisbon Treaty. More precisely, we show how the EP made strategic use of delaying and arena-linking in order to bring about an informal institutional change to its advantage. By comparing cases in which the EP succeeded and failed in bringing about such informal institutional change, we are able to identify crucial factors explaining the respective outcome. The delaying strategy will be effective only if the perceived urgency of making a certain decision is high. The success of arena-linkage, instead, depends on the distributional repercussion for the (most) powerful member states: if the EP links its institutional demand to an arena in which member states have a lot to lose, the strategy will fail.

Urgency is particularly high in times of crisis. Given that crises usually lead to a concentration of decision-making power with the executives, and arguably to a marginalization of the EP (Bressanelli and Chelotti 2016), the use of a delaying strategy may thus counteract this tendency. The opposite is true with regard to arena-linking. While the Lisbon Treaty formally empowered the EP in areas of 'core state powers' like 
migration policy or national budgetary control, arena-linking would not be a suitable strategy for reaching an informal extension of the new rights, as member states have much to lose in these policies (Genschel and Jachtenfuchs 2016).

Our findings come with several caveats. First, the EP's strategies have to be seen in the context of reactions and counter-strategies of other institutional actors which, by for instance shifting arenas to the European Council, may seek to circumvent the EP altogether. Second, even if the EP succeeds in obtaining informal institutional rules to its benefits, this does not mean that it can effectively use them to gain substantial influence on policy outcomes. With regard to the EU's economic governance, recent research has indeed suggested that the EP has not been able to translate its newly gained institutional powers into real influence (Bressanelli and Chelotti 2018; Fromage 2018).

Finally, our analysis is based on the theoretical assumption that the EP acts as a unified actor if institutional issues are at stake. If the EP is confronted with the opportunity to increase its own institutional power, it is indeed rare that individual MEPs express the wish not to do so (see Héritier 2007; O'Keeffe, Salines, and Wieczorek 2016). However, the EP may refrain from maximizing its power if an issue is of paramount societal importance. In this case, the EP may face a trade-off between a powermaximizing and a problem-solving behaviour (Scharpf 1997, 130-132), or it may not feel legitimate enough to engage in hard bargaining if this jeopardizes a superior collective outcome (see Bressanelli and Chelotti 2018; Ripoll Servent in this issue). The question as to when the EP opts for problem-solving instead of power-maximizing constitutes an important avenue for future research.

\section{Notes}

1. We define informal institutions as rules that are created outside the official channels of legislation (Helmke and Levitsky 2004, 725, 727) and that are not subject to third party dispute resolution and formal sanctions in case of non-abidance (Farrell and Héritier 2003).

2. Arena-linking differs from issue-linking, where in one arena two issues are linked by formal decision-makers to build a majority so that both issues are adopted. By contrast, arenalinking ties decision-making across two different arenas in that it links a substantive issue in one arena to an institutional issue in another arena. By withholding its support for a decision in an arena where it has full competences, the EP may obtain more informal institutional powers in another arena where it lacks such competences.

3. As regards monetary policy, Art. 284.3 makes the European Central Bank (ECB) accountable to the EP. The ECB must present an annual report on its activities and monetary policy to the EP, and the President of the ECB as well as the other members of the executive board may be heard by the EP's competent committees.

4. Empirically, O'Keeffe, Salines, and Wieczorek (2016) have shown that the EP's internal divides had only a very limited impact on its external cohesion in inter-institutional bargaining.

5. We regard inter-institutional agreements as informal institutions as they are created outside the official channels of legislation and are not subject to formal Court ruling. Strictly speaking, only the unilateral legal acts (regulations, directives, decisions) can be tried by the ECJ, but not the bi-/multilateral 'agreements' (except for the opinions the Court may give on draft international agreements). Legally, therefore, it is more appropriate for the Court not to enforce an inter-institutional agreement. However, the Court could comment on them indirectly by ruling about a context in which they play in. In doing so, the Court 
could use them as a source for interpretation. The Court could thus see the breach of a commitment in an inter-institutional agreement as 'evidence' of a breach of the legal principle of sincere cooperation (Personal communication by Carl-Fredrik Bergstrom, 6.9.2015).

6. Under 'delegated acts' the Commission by legislation may be delegated the power to adopt acts supplementing or amending certain non-essential elements of the legislation in question. Both the Council and the EP may prevent 'delegated acts' from entering into force within a certain period of time. Under 'implementing acts' the Commission may be given the power to provide detail to legislation that needs to be uniformly implemented across member states. As opposed to delegated acts, implementing acts are under the control of member states.

7. Only few weeks after the Commission had issued the two proposals, eurozone governments already urged 'the Council and the European Parliament to rapidly examine these regulations so that they will be in force for the next budgetary cycle' (European Council 2011, 4). In autumn 2012, for instance, the 'European Council invites the legislators to find an agreement with a view to adopting the "Two-Pack" by the end of 2012 at the latest' (European Council 2012a, 9). In December 2012, the European Council again stressed the 'immediate priority [...] to complete and implement the framework for stronger economic governance' and 'calls for its rapid adoption by the co-legislators' (European Council 2012b, 2).

8. More precisely, the Treaty amendment was supposed to 'neutralize' the no-bail-out-rule (Art. 125 TFEU) and to replace the legally 'shaky' Council Regulation No 407/2010, which provided for the EFSF, but not for a permanent rescue fund.

9. http://www.europarl.europa.eu/sides/getDoc.do?type=TA\&language=EN\&reference=P7-TA -2012-2 rev. 2018-06-08; see also http://www.europarl.europa.eu/news/en/press-room /20110322IPR16114/parliament-approves-treaty-change-to-allow-stability-mechanism rev. 2018-06-08.

10. For example, it obtained the Commission's promise to present a legal proposal to partly integrate the financial assistance under the ESM into community law (later one of the TwoPack regulations).

11. A supportive argument is put forward by Schimmelfennig when he argues that 'institutions of financial assistance are more intergovernmental than institutions of supervision' (Schimmelfennig 2015,189 ) as more powerful creditor states want to stay in control over the institutions that commit themselves and at the same time increase the credibility of those institutions constraining the (weaker) debtor states.

\section{Acknowledgments}

Earlier versions of this article were presented at the workshop "The European Parliament in the new Europe: Institutional Power and policy influence?" at King's College London, 26 May 2017, and at an organized panel of the ECPR Pan-European Conference on the European Union in Paris, 15 June 2018. We thank the organizers, Edoardo Bressanelli and Nicola Chelotti, and the participants for helpful feedback. Moreover, we gratefully acknowledge valuable discussions with Catherine Moury and Katharina Meissner as well as the comments of two anonymous reviewers.

\section{Disclosure statement}

No potential conflict of interest was reported by the authors.

\section{Funding}

This work was supported by the Swedish Research Council under Grant No 2016-01596. 


\section{References}

Alcidi, C., A. Giovannini, and S. Piedrafita. 2014. "Enhancing the Legitimacy of EMU Governance, Study for the ECON Committee, European Parliament, Directorate-General for Internal Policies, Policy Department A: Economic and Scientific Policy, Brussels." Accessed 08 June 2018. http:// www.europarl.europa.eu/RegData/etudes/STUD/2014/536312/IPOL_STU(2014)536312_EN.pdf

Angelini, P., and G. Grande. 2014. "How to Loosen the Banks-Sovereign Nexus." VOX, April 8. Accessed 22 May 2017. http://voxeu.org/article/how-loosen-banks-sovereign-nexus

Bouwen, P., and J. Fischer. 2012. "Toward a Stronger EU Surveillance of Macroeconomic Imbalances: Rationale and Design of the New Procedure." Reflets et Perspectives de la Vie Économique 2012/1: 21-31. doi:10.3917/rpve.511.0021.

Bressanelli, E., and N. Chelotti. 2016. "The Shadow of the European Council: Understanding Legislation on Economic Governance." Journal of European Integration 38 (5): 511-525. doi:10.1080/07036337.2016.1178251.

Bressanelli, E., and N. Chelotti. 2018. "The European Parliament and Economic Governance: Explaining a Case of Limited Influence." Journal of Legislative Studies 24 (1): 72-89. doi:10.1080/13572334.2018.1444627.

Collier, D., and J. Mahoney. 1996. "Insights and Pitfalls: Selection Bias in Qualitative Research." World Politics 49 (1): 56-91. doi:10.1353/wp.1996.0023.

Crum, B. 2018. "Parliamentary Accountability in Multilevel Governance: What Role for Parliaments in Post-Crisis EU Economic Governance?" Journal of European Public Policy 25 (2): 268-286. doi:10.1080/13501763.2017.1363270.

De Witte, B. 2011. The European Treaty Amendment for the Creation of a Financial Stability Mechanism. Stockholm: European Policy Analysis 6epa, Swedish Institute for European Policy Studies.

European Central Bank and European Parliament. 2013. "Interinstitutional Agreement between the European Parliament and the European Central Bank on the Practical Modalities of the Exercise of Democratic Accountability and Oversight over the Exercise of the Tasks Conferred on the ECB within the Framework of the Single Supervisory Mechanism, 2013/694/EU." Accessed 09 November 2017. https://www.ecb.europa.eu/ecb/legal/pdf/celex_32013q113001_en_txt.pdf

European Council. 2011. Statement by the Euro Area Heads of State or Government. Brussels, December 9. Brussels: European Council.

European Council. 2012a. Conclusions. October 19. Brussels: European Council.

European Council. 2012b. Conclusions. December 14. Brussels: European Council.

Farrell, H., and A. Héritier. 2003. "Formal and Informal Institutions under Codecision: Continuous Constitution Building in Europe." Governance 16 (4): 577-600. doi:10.1111/gove.2003.16.issue-4.

Farrell, H., and A. Héritier. 2007. "Codecision and Institutional Change." West European Politics 30 (2): 285-300. doi:10.1080/01402380701239723.

Fasone, C. 2014. "European Economic Governance and Parliamentary Representation. What Place for the European Parliament?" European Law Journal 20 (2): 164-185. doi:10.1111/eulj.2014.20. issue- 2 .

Fromage, D. 2018. "The European Parliament in the Post-Crisis Era: An Institution Empowered on Paper Only?" Journal of European Integration 40 (3): 281-294. doi:10.1080/ 07036337.2018.1450405.

Genschel, P., and M. Jachtenfuchs. 2016. "More Integration, Less Federation: The European Integration of Core State Powers." Journal of European Public Policy 23 (1): 42-59. doi:10.1080/ 13501763.2015.1055782.

George, A. L., and A. Bennett. 2005. Case Studies and Theory Development in the Social Sciences. Cambridge, MA: MIT Press.

Gino, F., and D. Moore. 2008. "Using Final Deadlines Strategically in Negotiation." Negotiation and Conflict Management Research 1 (4): 371-388. doi:10.1111/ncmr.2008.1.issue-4.

Helmke, G., and S. Levitsky. 2004. "Informal Institutions and Comparative Politics." Perspectives on Politics 2 (4): 725-740. doi:10.1017/S1537592704040472.

Héritier, A. 2007. Explaining Institutional Change in Europe. Oxford: Oxford University Press. 
Hix, S., and B. Høyland. 2013. "Empowerment of the European Parliament." Annual Review of Political Science 16 (1): 171-189. doi:10.1146/annurev-polisci-032311-110735.

Knight, J. 1992. Institutions and Social Conflict. Cambridge: Cambridge University Press.

Knight, J. 1995. "Models, Interpretations, and Theory: Constructing Explanations of Institutional Emergence and Change." In Explaining Social Institutions, edited by J. Knight and I. Sened. Ann Arbor: University of Michigan Press, 95-160.

Krasner, S. D. 1991. "Global Communication and National Power: Life on the Pareto Frontier." World Politics 43 (3): 336-366. doi:10.2307/2010398.

Lake, D., and R. Powell. 1999. "International Relations: A Strategic Choice Approach." In Strategic Choice and International Relations, edited by D. Lake and R. Powell. Princeton, NJ: Princeton University Press, 3-38.

Library of the European Parliament. 2012. "Parliament's Role in Anti-Crisis Decision-Making." Library Briefing 17/12/2012, Author: Eva-Maria Poptcheva. doi:10.1094/PDIS-11-11-0999PDN.

North, D. 1990. Institutions, Institutional Change and Economic Performance. Cambridge: Cambridge University Press.

O'Keeffe, M., M. Salines, and M. Wieczorek. 2016. "The European Parliament's Strategy in EU Economic and Financial Reform." Journal of European Public Policy 23 (2): 217-235. doi:10.1080/13501763.2015.1025091.

Reh, C., A. Héritier, E. Bressanelli, and C. Koop. 2011. "The Informal Politics of Legislation: Explaining Secluded Decision Making in the European Union." Comparative Political Studies 46 (9): 1112-1142. doi:10.1177/0010414011426415.

Rittberger, B. 2003. "The Creation and Empowerment of the European Parliament." Journal of Common Market Studies 41 (2): 203-225. doi:10.1111/1468-5965.00419.

Rittberger, B. 2014. "Integration without Representation? the European Parliament and the Reform of Economic Governance in the EU." Journal of Common Market Studies 52 (6): 1174-1183. doi:10.1111/jcms.12185.

Scharpf, F. W. 1997. Games Real Actors Play: Actor-Centered Institutionalism in Policy Research. Boulder, CO: Westview Press.

Scherpereel, J. A., and L. K. Perez. 2015. "Turnover in the Council of the European Union: What It Is and Why It Matters." Journal of Common Market Studies 53 (3): 658-673. doi:10.1111/ jcms.12214.

Schimmelfennig, F. 2015. "Liberal Intergovernmentalism and the Euro Area Crisis." Journal of European Public Policy 22 (2): 177-195. doi:10.1080/13501763.2014.994020.

Sebenius, J. K. 1992. "Changing Conventional Explanations of International Cooperation: Negotiation Analysis and the Case of Epistemic Communities." International Organization 46 (1): 323-365. doi:10.1017/S0020818300001521.

Sened, I. 1991. "Contemporary Theory of Institutions in Perspective." Journal of Theoretical Politics 3 (4): 379-402. doi:10.1177/0951692891003004002.

Snidal, D. 1996. "Political Economy and International Institutions." International Review of Law and Economics 16 (1): 121-137. doi:10.1016/0144-8188(95)00051-8.

TSCG. 2012. "Treaty on Stability, Coordination and Governance in the Economic and Monetary Union." Accessed 29 November 2013. http://european-council.europa.eu/media/639235/ st00tscg26_en12.pdf

Warren, T. 2018. "The European Parliament and the Eurozone Crisis: An Exceptional Actor?" The British Journal of Politics and International Relations 20: 632-651. Advance online publication. doi:10.1177/1369148118768141.

Weidmann, J. 2013. "Stop Encouraging Banks to Buy Government Debt." Financial Times, February 8. http://www.ft.com/intl/cms/s/0/81a505a4-278c-11e3-8feb-00144feab7de.html

\section{Interviews}

Interview 1. 2015. European Parliament, senior official. Brussels, Belgium, 2 February. 
Interview 2. 2015. European Parliament, MEP, Brussels, Belgium, 4 February.

Interview 3. 2015. European Parliament, senior official. Brussels, Belgium, 6 February.

Interview 4. 2015. General Secretariat of the Council. Brussels, Belgium, 9 February.

Interview 5. 2015. European Parliament, senior official. Brussels, Belgium, 10 February.

Interview 6. 2015. EU officials. Brussels, Belgium, 11 February.

Interview 6T. 2014. European Commission, DG ECFIN, senior official. Brussels, Belgium, 14 November.

Interview 7. 2015. General Secretariat of the Council, senior official. Brussels, Belgium, 11 February. Interview 8. 2015. European Parliament, senior official. Brussels, Belgium, 12 February. 